\title{
Cactus Bug, Chelinidea vittiger aequoris McAtee (Insecta: Hemiptera: Coreidae) ${ }^{1}$
}

\section{F. W. Mead and J. L. Herring ${ }^{2}$ \\ Introduction}

Insects that attack prickly pear cacti, Opuntia spp., in North America have been under investigation for a century. The primary purpose of this research has been to determine which insects have the most promise as biocontrol agents where cacti are severe weed problems. In Australia, for example, over 30,000,000 acres of pasture land were rendered useless because of dense stands of exotic prickly pear cacti. One of the native American cactus insects that showed early promise as a control agent was the coreid bug, Chelinidea vittiger Uhler. DeVol and Goeden (1973) discussed the value of this species in biological weed control and reported that it was ineffective in controlling prickly pears in Australia and Santa Cruz Island, California. In most areas of North America prickly pears are not a problem because a complex of insects keeps them under control. Chelinidea vittiger is considered a minor component of that complex. In Florida and the other southeastern states, the only Chelinidea present is $C$. vittiger aequoris McAtee.

\section{Systematics}

The principal systematic treatments of North American Chelinidea have been provided by McAtee (1919), Hamlin (1924), and Torre-Bueno (1941). McAtee (1919) recognized two species of Chelinidea from the Nearctic region and divided $C$. vittiger into two subspecies by his description of the new subspecies aequoris. He saw color variations in each subspecies and provided formal varietal names for these forms. Within C. v. aequoris he described the new variety artuatra. Florida specimens of Chelinidea generally fit the latter color form of aequoris. The description of typical C.v. aequoris is based on Texas specimens. Hamlin (1924) reviewed the genus Chelinidea after studying specimens from the United States and Mexico for several years. He repeated descriptions of new species first published in 1923, provided a key to the four species in the genus, and agreed with McAtee's treatment of $C$. vittiger.

1. This document is EENY-208 (originally published as DPI Entomology Circular 149), one of a series of Featured Creatures from the Entomology and Nematology Department, Florida Cooperative Extension Service, Institute of Food and Agricultural Sciences, University of Florida. Published: May 2001. Revised: August 2003. This document is also available on Featured Creatures Website at http://creatures.ifas.ufl.edu. Please visit the EDIS Website at http://edis.ifas.ufl.edu and the Entomology and Nematology Department website at http://entnemdept.ifas.ufl.edu/. 2. F. W. Mead and J. L. Herring, Florida Department of Agriculture and Consumer Services, Division of Plant Industry, Gainesville, FL.

The Institute of Food and Agricultural Sciences (IFAS) is an Equal Employment Opportunity - Affirmative Action Employer authorized to provide research, educational information and other services only to individuals and institutions that function without regard to race, creed, color, religion, age, disability, sex, sexual orientation, marital status, national origin, political opinions or affiliations. For information on obtaining other extension publications, contact your county Cooperative Extension Service office. Florida Cooperative Extension Service / Institute of Food and Agricultural Sciences / University of Florida / Larry R. Arrington, Interim Dean 


\section{Distribution}

Chelinidea vittiger, in its various forms, ranges from California to Virginia, northward to Montana, and southward to northern Mexico. Hamlin (1932) showed Central Florida as the southeastern U.S. limit of C. v. aequoris.

Hamlin (1924) apparently was the first to report Chelinidea vittiger aequoris from Florida (at Gainesville). He did not report it elsewhere in Florida, but took live specimens to Miami where he reared them on Opuntia spp. A specimen in the U.S. National Museum of Natural History labeled Miami, Florida (no other data), probably came from this laboratory colony. We do not know of a valid Dade County record for Chelinidea. Blatchley (1926) did not list any Florida records of Chelinidea. Hussey (1952) listed three Florida records of C. v. aequoris.

\section{Description and Identification}

The adult has a length of 10 to $13.5 \mathrm{~mm}$; width across pronotum 4 to $5 \mathrm{~mm}$. The most striking features of $C$. vittiger aequoris are a conspicuous dorsal, yellow stripe on the head, nearly solid yellow pronotum, and yellow veins of the forewing. General appearance is similar to the better known squash bugs (Anasa spp.) which lack the extensive yellow pronotum and the yellowish veins of the corium and clavus that starkly contrast with the generally dark hemelytra. This contrast is less apparent in other forms and species of Chelinidea. Other notable yellowish areas of specimens from Florida are the entire venter, basal half of costal margin of corium, and exposed margin of the abdomen. Florida specimens have the antennae, most of head, legs, and hemelytra dark brown to blackish. The membrane of the forewing often has a greenish cast and is generally darker than the leathery basal portion. A black transverse bar is nearly always present at the base of the pronotum. The antennae have a slightly dilated appearance which, on close inspection, reveal 3-sided (prism- shaped) 2nd and 3rd segments (also present in older nymphs). An overall feature of Chelinidea is the glabrous appearance.

Hunter et al. (1912) described the egg and five nymphal stages of Chelinidea vittiger. Hamlin (1924) gave detailed descriptions of the egg and each instar

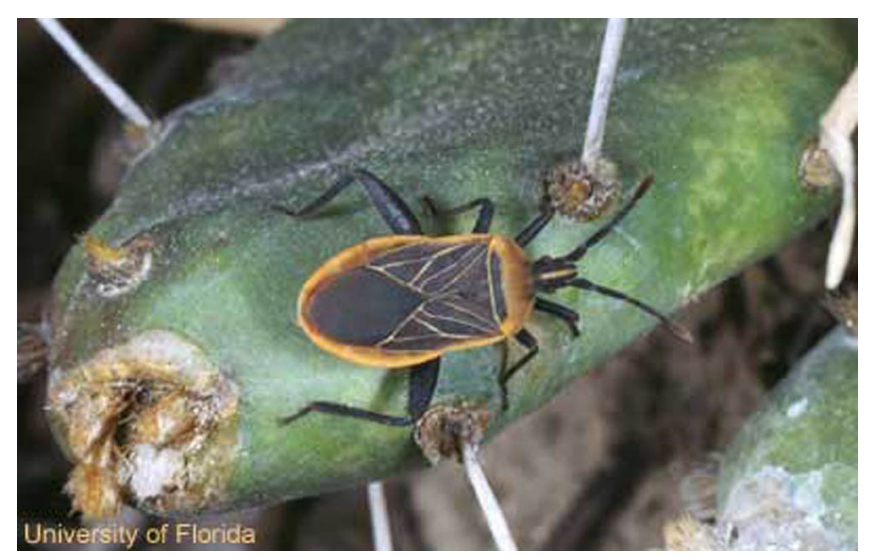

Figure 1. The cactus bug, Chelinidea vittiger aequoris McAtee, on an Opuntia cactus. Credits: Lyle Buss, University of Florida

(stage) of C. v. aequoris. He also listed color changes that occur from one instar to another and described three color forms within the 5 th instar.

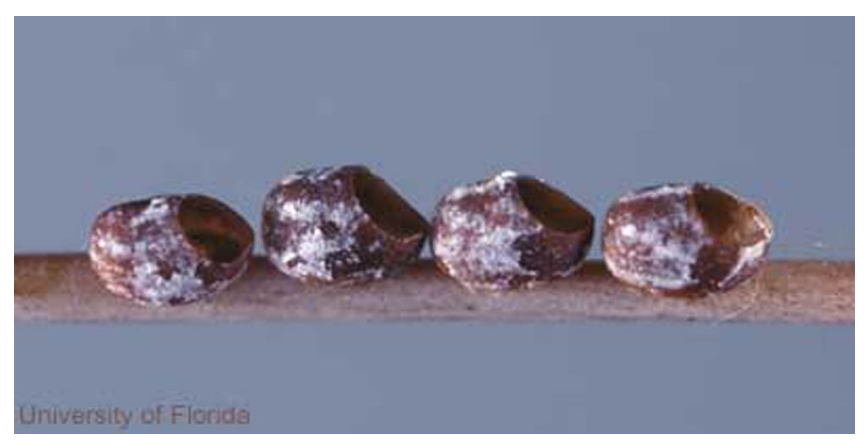

Figure 2. Eggs of Chelinidea vittiger aequoris McAtee, a cactus bug, on prickly pear spine. Credits: Lyle J. Buss, University of Florida

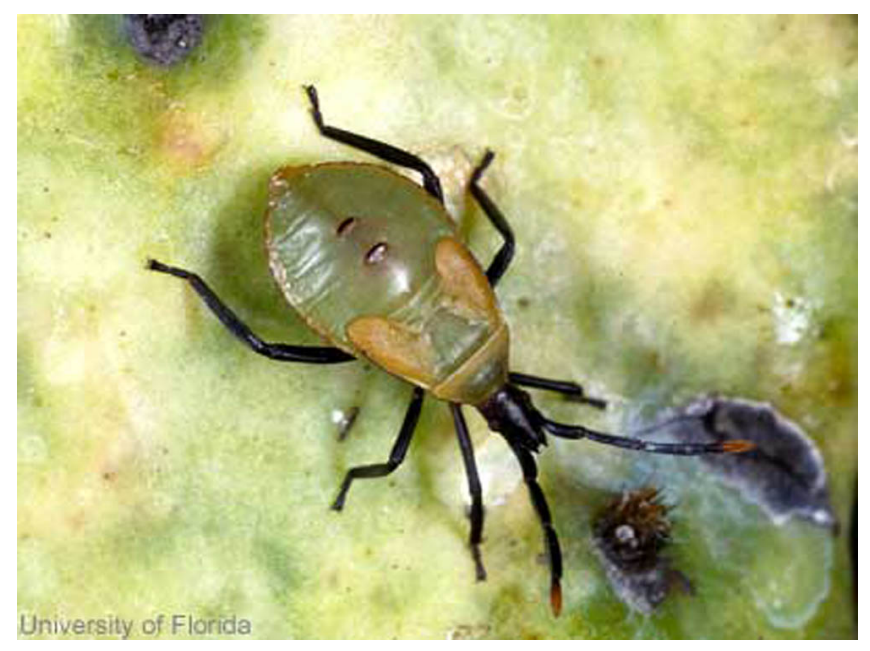

Figure 3. Nymph of Chelinidea vittiger aequoris McAtee, a cactus bug that feeds on pricklypear cacti, Opuntia spp. Feeding punctures result in circular discolored areas. Credits: Lyle J. Buss, University of Florida 


\section{Bionomics}

Consult Hunter et al. (1912), Hamlin (1924, 1932), Mann (1969), and DeVol and Goeden (1973) for reviews on economics and biology of Chelinidea spp. Their economic status depends on whether the host cactus plants are weeds, ornamentals, reserve forage, or hosts for the dye-producing cochineal scales, Dactylopius spp. Native prickly pears in Florida are widespread but usually are kept at tolerable levels by a combination of environmental factors, including scales, moths, beetles, coreids, fungus diseases, etc. Mann (1969) believed that Chelinidea spp. exercise a greater degree of control in preventing growth and fruiting than in destroying cactus pads. All stages of these cactus bugs are associated with cacti. C. v. aequoris is one of the forms that feeds primarily on cacti in subgenus Platyopuntia of Opuntia. Hamlin (1924) reported hibernation normally occurring from the first part of December to mid-March in Florida, usually as adults but occasionally as large nymphs.

First eggs of the season are deposited in March, longitudinally on the underside of prickly pear spines. The egg laying period in each generation extends over two to three months, the rate of nymphal development varies considerably, and adults are long lived (nine to 12 months under field conditions; a reared female of $C$. vittiger survived for 542 days under cage conditions in Australia according to Mann). Thus during warm weather it is possible to have several stages present, contributing to confusion on the number of broods per year. For example, Hamlin $(1924,1932)$ suggested four to five broods annually, but Mann (1969) listed only two generations per year for $C$. vittiger aequoris. DeVol and Goeden (1973) reported C. v. vittiger as univoltine in southern California. Data on Florida specimens seen by us are for April to October, although literature records add the other months except January. Hamlin (1924) remarked that, with few exceptions, cactus feeding insects (including Chelinidea) are sluggish. He ascribed this habit to their association with host plants that afford a high degree of protection because of their spines.

\section{Detection}

- Adults and nymphs feed chiefly in colonies on the more distal prickly pear joints, but also to some extent on the fruits and older joints. Look for eggs on the cactus spines.

- Search for inactive bugs during cold weather under debris at the base of the cactus plants or under prostrate joints.

- The first indications of feeding are lighter circular spots on the cactus joints (pads) which appear only after feeding has progressed for some time. Conspicuous, white Chelinidea excrement may cover the surface of the joint.

- As injury proceeds, the spots become larger and coalesce; the entire epidermis assumes deadened, yellowish, and pitted appearance.

- Secondary invasion by fungi causes large black spots that can result in the infected areas dropping out, leaving a nearly circular opening through the joint, or an entire pad may drop off.

\section{Selected References}

Blatchley WS. 1926. Heteroptera or true bugs of Eastern North America, with especial reference to the faunas of Indiana and Florida. Nature Publishing Company, Indianapolis. $1116 \mathrm{p}$.

DeVol JE, Goeden RD. 1973. Biology of Chelinidea vittiger with notes on its host- plant relationships and value in biological weed control. Environmental Entomology 2: 231-240.

Hamlin JC. 1924. A review of the genus Chelinidea (Hemiptera-Heteroptera) with biological data. Annals of the Entomological Socienty of America Publishing Company. 25: 89-120.

Hunter WD, Pratt FC, Mitchell JD. 1912. The principal cactus insects of the United States. U.S.D.A. Bureau of Entomology Bulletin 113: 1-71.

Hussey RF. 1952. Food plants and new records for some Hemiptera in Florida. Florida Entomolgist 35: 117-118. 
Mann J. 1969. Cactus-feeding insects and mites.

U.S. National Museum Bulletin. 256: 1-158.

McAtee WL. 1919. Notes on Nearctic

Heteroptera. Bulletin of the Brooklyn Entomological

Society 14: 8-15.

Torre-Bueno de la JR. 1941. A synopsis of the Hemiptera-Heteroptera of America north of Mexico.

Part II. Families Coreidae, Alydidae, Corizidae, Neididae, Pyrrhocoridae and Thaumastotheriidae.

Entomological Americana 21: 41-122. 